$\underline{\xi}=-m$

\title{
The potential beneficial effect of exenatide on cisplatin induced nephrotoxicity in non-diabetic rats
}

\author{
Eman Abdel-Mohsen Abdel-Aziz ${ }^{1}$, Sahar M. Abo El Wafa ${ }^{2} *$ \\ ${ }^{1}$ Department of Pharmacology, Faculty of Medicine, Benha University, Benha, Egypt \\ ${ }^{2}$ Department of Forensic Medicine and Clinical Toxicology, Faculty of Medicine, Benha University, Benha, Egypt \\ *Corresponding author E-mail: saharabouelwafa32@yahoo.com
}

\begin{abstract}
Background: Cisplatin is a major antitumor drug used for treatment of solid tumors. Nephrotoxicity is its main limiting side effect. Exenatide is described as an incretin mimetic polypeptide, it acts as a GLP-1 receptor agonist and its insulinotropic activity is mediated through binding to and stimulation of GLP-1 receptors on human pancreatic $\beta$-cells. Aim: the present work was designed to study the effect of exenatide on experimentally cisplatin induced nephropathy in non- diabetic rats. Materials and Methods: Thirty two male adult Sprague Dawley rats randomly divided into four groups, each consisted of 8 animals, and distributed as follows: Group I: (control) normal group and received saline vehicle. Group II: (cisplatin) group includes rats injected intraperitoneally by a single dose of cisplatin (6 $\mathrm{mg} / \mathrm{kg}$ ) to induce nephrotoxicity, received no treatment and were sacrificed 7 days after cisplatin administration. Group III: (exenatide) group: rats treated by exenatide $(10 \mathrm{mg} / \mathrm{kg} / \mathrm{day}$ s.c.) for 4 weeks. Group IV: (exenatide+cisplatin) group: rats treated by exenatide (10 $\mathrm{mg} / \mathrm{kg} /$ day s.c.) for 4 weeks before induction of nephrotoxicity by cisplatin. The following parameters were measured: fasting blood glucose, serum urea, serum creatinine, reduced glutathion (GSH) level in the renal tissue, tumor necrosis factor- $\alpha$ (TNF- $\alpha$ ) level in the renal tissue, renal blood flow changes and histopathological changes of the kidney. Results: Pretreatment with exenatide resulted in significant reduction in serum urea, serum creatinine level and renal TNF- $\alpha$ level compared to cisplatin group but still significantly higher than control group with significant increase in renal GSH level and renal blood flow compared to cisplatin group but still also significantly lower than control group. Cisplatin group showing tubular degeneration with infiltration of inflammatory cells while pretreatment with exenatide showing certain improvement in general histological structure with mild tubular degeneration and less inflammatory cell infiltration. Conclusion: it can be concluded that the use of exenatide improved the biochemical and histopathological changes that occur in the renal tissue by cisplatin.
\end{abstract}

Keywords: Antioxidant; Cisplatin; Exenatide; Nephrotoxicity.

\section{Introduction}

The kidney has a vital role in drug elimination. It is well known that the kidney is one of the organs with high blood flow; it is supplied by $25 \%$ of cardiac output. Therefore, the kidney is exposed to high concentrations of drugs and metabolites, giving a chance of drug toxicity induction. It is therefore not surprising that $25 \%$ of all cases of acute renal failure were resulted from drug administration (Decloedt and Maartens, 2011). Cisplatin is an effective antitumor drug used for treatment of solid tumors. Nephrotoxicity is considered its main limiting side effect. Twenty percent of patients receiving high-doses of cisplatin have renal dysfunction. Several investigations were carried out to reveal the mechanism of this renal cell injury, and some studies suggest that inflammation, oxidative stress and apoptosis probably explain a part of this injury (Hasiyeti et al., 2013). Exenatide is described as an incretin mimetic polypeptide, it acts as a GLP-1 receptor agonist and its insulinotropic activity is mediated through binding to and stimulation of GLP-1 receptors on $\beta$-cells of pancreas (Koole et al., 2017). Exenatide is approved as an adjunctive S.C therapy to improve glycemic control in diabetic patients not achieving adequate glycemic control while taking metformin, a sulfonylurea, a thiazolidinedione, or a combination of these oral agents (Holman et al., 2017).

To the best of our knowledge, there are no studies concerning the possible renoprotective effect of exenatide in non-diabetic rats so, the present work was designed to study the effect of exenatide on experimentally induced nephropathy in non- diabetic rats in order to reveal the ability of exenatide to protect the kidney even in absence of hyperglycemia and diabetes mellitus.

\section{Material and methods}

\subsection{Drugs and chemicals}

a) Exenatide: It was purchased from Sigma-Aldrich Chemical Co. It was supplied as a sterile solution for subcutaneous injection $(250 \mu \mathrm{g} / \mathrm{ml})$. 
b) Cisplatin: (Oncotec Pharma Production GmbH. Germany). It is available as vials.

c) All drugs and other chemicals used were of the high analytical grade.

\subsection{Animals}

Thirty two male adult Sprague Dawley rats weighing 150-200 g were obtained from Experimental Animal Breeding Farm, (HelwanCairo). They were caged 8 per cage in well ventilated place at room temperature. They allowed free water and standard food (pellets specific for rat feeding obtained from animal breeding farm) for 7 days for acclimatization.

\subsection{Study design}

The rats randomly divided into four groups, each consisted of 8 animals, and distributed as follows:

Group I: (control) normal group and received saline vehicle.

Group II: (cisplatin) group includes rats injected intraperitoneally by a single dose of cisplatin $(6 \mathrm{mg} / \mathrm{kg})$ to induce nephrotoxicity and received no treatment. Rats were sacrificed 7 days after cisplatin administration (Saad and Al-Rikabi, 2002).

Group III: (exenatide) group: rats treated by exenatide (10 mg/kg/day s.c.) for 4 weeks (Tanaka et al., 2014).

Group IV: (exenatide+cisplatin) group: rats treated by exenatide $(10 \mathrm{mg} / \mathrm{kg} / \mathrm{day})$ s.c. for 4 weeks before induction of nephrotoxicity by cisplatin.

The following parameters were measured: fasting blood glucose, serum urea, serum creatinine, reduced glutathion (GSH) level in the renal tissue, tumor necrosis factor- $\alpha(\mathrm{TNF}-\alpha)$ level in the renal tissue, renal blood flow changes and histopathological changes of the kidney.

\subsection{Procedural details}

\subsubsection{Measurement of renal blood flow}

At the end of experiment, after complete anesthesia, the rats were put on their back. Then the abdominal cavity of each rat was opened through a median incision and the left renal artery was exposed. Bi-directional blood flowmeter with FFT analysis (Hadeco, Japan) was used. After setting the mode of pulsed Doppler blood flowmeter, we use ultrasonic gel on the probe top and turn the volume control to the maximum. The probe pressed softly to the measurement area and at an angle of $45-60^{\circ}$. After hearing the optimal sounds, we wait for 5 seconds without moving the probe then press the freeze key to freeze the waveform (Haywood et al., 1981) then blood samples were taken from the heart (Parasuraman et al., 2010). Samples were incubated at 370C until blood clotted and then centrifuged at 3000 revolution per minute (rpm) for 15 min for separation of serum and stored at $-20 \mathrm{oC}$ for biochemical analysis of serum urea and serum creatinine. Both kidneys were removed and the upper $1 / 3$ of each kidney was put into a buffered $4 \%$ formaline fixation solution and processed with paraffin wax for histopathological examination. Sections $(5 \mu \mathrm{m})$ were stained with hematoxylin and eosin (Dury and Wallington, 1967). Another portion was used to prepare renal tissue homogenate to determine tissue level of reduced glutathione (GSH) and tumor necrosis factor alpha $(\mathrm{TNF}-\alpha)$.

\subsubsection{Measurement of Fasting blood glucose levels (F.B.G)}

The fasting blood glucose level was measured on a Beckman Glucose Analyzer II. Separation of glucose was achieved by dimedone precipitation and expressed as milligrams per deciliter (Efendic et al., 1988).

\subsubsection{Measurement of serum urea}

Urea in the sample is hydrolyzed enzymatically into ammonia (NH4) and carbon dioxide (CO2). Ammonia ions formed reacts with salicylate and hypochlorite $(\mathrm{NaClO})$, in presence of the catalyst nitroprusside, to form green indophenols. The intensity of the color formed is proportional to the urea concentration in the sample (Kaplan, 1984).

\subsubsection{Measurement of serum creatinine}

The assay is based on the reaction of creatinine with sodium picrate. Creatinine reacts with alkaline picrate forming a red complex. The time interval chosen for measurement avoids interference from other serum constituents. The intensity of the color formed is proportional to the creatinine concentration in the sample (Murray, 1984).

\subsubsection{Measurement of reduced glutathione (GSH) level in renal tissue}

Kidney homogenate preparation: a portion of isolated kidney tissue from each rat was homogenized in a $100 \mathrm{mmol} \mathrm{KCl}$ buffer $(7.0 \mathrm{p} \mathrm{H})$ containing EDTA $0.3 \mathrm{mM}$, All homogenates were centrifuged at $600 \mathrm{~g}$ for 60 minutes at $4 \mathrm{oC}$ and protein content of the supernate was measured and then used for biochemical assays (Noori et al., 2009). GSH level in renal tissues was measured by colorimetric method based on the reduction of 5, 5'- dithionitrobenzoic acid (DTNB) with GSH to produce a yellow compound. The reduced chromogens directly proportional to GSH concentration and its absorbance can be measured at $405 \mathrm{~nm}$. Values were expressed as nmol/mg protein.

\subsubsection{Estimation of tumor necrosis factor alpha (TNF- $\alpha)$ level in renal tissue}

TNF- $\alpha$ concentration in renal tissues was measured by using USA \& Canada. R\&D Systems, Inc kit, according to manufacturer,s protocol.

\subsection{Statistical analysis}


Results are presented as mean \pm standard deviation (mean $\pm \mathrm{SD}$ ). Statistical analysis was performed using one-way analysis of variance (ANOVA) to detect significant differences between the group means. Probability $(\mathrm{P})$ values of $<0.05$ were considered as statistically significant.

\section{Results}

\subsection{Biochemical results}

In this work single i.p injection of cisplatin $(6 \mathrm{mg} / \mathrm{kg})$ did not produce significant change on FBG level. Exenatide group showed insignificant change in serum urea, serum creatinine level, intrarenal GSH level, intrarenal TNF- $\alpha$ level and renal blood flow compared to control group. Cisplatin administration resulted in significant increase $(\mathrm{p}<0.05)$ in serum urea, serum creatinine level and renal TNF- $\alpha$ level with significant reduction $(\mathrm{p}<0.05)$ in renal GSH level and renal blood flow compared to control group. Pretreatment with exenatide resulted in significant reduction $(\mathrm{p}<0.05)$ in serum urea, serum creatinine level and renal TNF- $\alpha$ level compared to cisplatin group but still significantly higher than control group with significant increase $(\mathrm{p}<0.05)$ in renal GSH level and renal blood flow compared to cisplatin group but still significantly lower than control group.

Table (1): Effect of exenatide administration $(10 \mathrm{mg} / \mathrm{kg} /$ day $)$ s.c. for 4 weeks before induction of nephrotoxicity by cisplatin [induced by i.p injection of a single dose of cisplatin $(6 \mathrm{mg} / \mathrm{kg})]$ on FBG, Serum urea, Serum creatinine, intrarenal GSH, intrarenal TNF- $\alpha \&$ Renal blood flow.

\begin{tabular}{|c|c|c|c|c|c|c|}
\hline Groups & $\begin{array}{l}\mathrm{FBG} \\
\mathrm{mg} / \mathrm{dl} \\
\text { Mean } \pm \mathrm{SD}\end{array}$ & $\begin{array}{l}\text { Serum urea } \\
\mathrm{Mg} / \mathrm{dl} \\
\text { Mean } \pm \mathrm{SD}\end{array}$ & $\begin{array}{l}\text { Serum creatinine } \\
\mathrm{Mg} / \mathrm{dl} \text { Mean } \pm \mathrm{SD}\end{array}$ & $\begin{array}{l}\text { GSH } \\
\text { nmol/mg potein } \\
\text { Mean } \pm \text { SD }\end{array}$ & $\begin{array}{l}\mathrm{TNF} \alpha \\
\mathrm{Ug} / \mathrm{mg} \text { protein } \\
\text { Mean } \pm \text { SD }\end{array}$ & $\begin{array}{l}\text { Renal blood flow } \\
\text { M1/Min } \\
\text { Mean } \pm \text { SD }\end{array}$ \\
\hline $\begin{array}{l}\text { Control } \\
\text { Group }\end{array}$ & $86 \pm 3.6$ & $27.63 \pm 1.5$ & $0.67 \pm 0.03$ & $43.12 \pm 0.9$ & $49.64 \pm 0.16$ & $11.3 \pm 0.8$ \\
\hline $\begin{array}{l}\text { Cisplatin } \\
\text { Group }\end{array}$ & $84 \pm 3.2$ & $89.35 \pm 0.17^{\mathrm{a}}$ & $1.94 \pm 0.02^{\mathrm{a}}$ & $23.59 \pm 1.2^{\mathrm{a}}$ & $180.45 \pm 0.18^{a}$ & $2.5 \pm 1.4^{\mathrm{a}}$ \\
\hline Exenatide Group & $85 \pm 2.4$ & $28.23 \pm 1.2^{\mathrm{b}}$ & $0.7 \pm 0.02^{b}$ & $41.33 \pm 1.8^{b}$ & $49.72 \pm 0.13^{b}$ & $10.8 \pm 0.9^{b}$ \\
\hline
\end{tabular}

Data are presented as mean $(\mathrm{M}) \pm \mathrm{SD}$

a: Significant difference versus control at $\mathrm{p}<0.05$

b: Significant difference versus cisplatin group at $\mathrm{p}<0.05$

c: Significant difference versus exenatide group at $\mathrm{p}<0.05$

\subsection{Histopathological results}
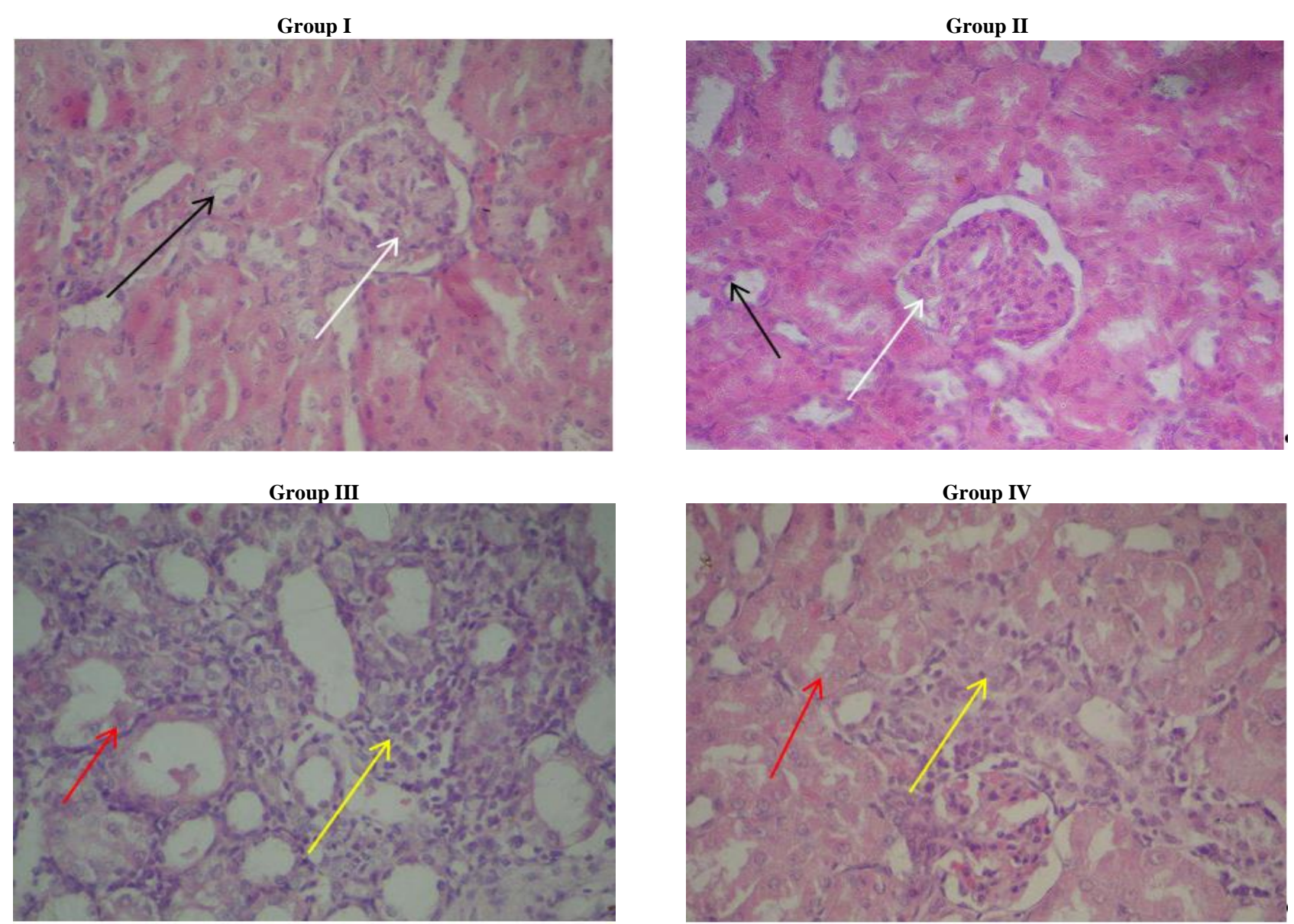

Fig. 1: Photomicrographs of Cut Sections in the Kidney of Different Groups (H\&Ex40) Showing: Normal Lobulation of Glomeruli (White Arrow) \& Normal Renal Tubules (Black Arrow) in Group I (Normal Control) and Group II (Exenatide Group) While in Group III (Cisplatin Group) Showing Sever 
Inflammatory Cell Infiltration (Yellow Arrow) with Necrosis of Renal Tubules (Red Arrow). on the Contrary, Group IV (Exenatide + Cisplatin) Showing General Improvement of the Histopathological Picture Regarding Inflammatory Cell Infiltration (Yellow Arrow) And Necrosis of Renal Tubules (Red Arrow).

Histopathological examination revealed that both control group and exenatide group showed normal lobulation of glomeruli \& normal renal tubules. None treated group (cisplatin group) showing tubular degeneration with infiltration of inflammatory cells. Rats treated with exenatide before induction of nephropathy by cisplatin showing certain improvement in general histological structure with mild tubular degeneration and less inflammatory cell infiltration Fig. (1).

\section{Discussion}

In this work single intraperitoneally injection of cisplatin $(6 \mathrm{mg} / \mathrm{kg})$ did not produce significant change on FBG level, this is consistent with (Bhoomika et al., 2013) while single intraperitoneally injection of cisplatin $(6 \mathrm{mg} / \mathrm{kg}$ ) resulted in significant increase of serum creatinine, serum urea, and this is in line with (Mohamed et al., 2014). TNF- $\alpha$ level and reduced glutathione (GSH) level in renal tissue were measured to demonstrate the pathophysiological mechanisms involved in cisplatin induced nephrotoxicity. Single intraperitoneally injection of cisplatin $(6 \mathrm{mg} / \mathrm{kg})$ resulted in significant increase of TNF- $\alpha$ level in renal tissue with significant reduction of reduced glutathione (GSH) level in renal tissue, this in line with (Ozkok and Charles, 2014).

The mechanism for cisplatin renal cell injury was demonstrated by Hasiyeti et al. (2013) who reported that cisplatin is a major antitumor drug used for the treatment of solid tumers.

The mechanism involved in cisplatin-induced nephrotoxicity includes inhibition of protein synthesis, DNA damage, mitochondrial injury and apoptotic cell death in renal tubules. Cisplatin reduces the bioavailability of nitric oxide (NO), which up regulates monocyte chemoattractant protein-1, connective tissue growth factors and tumor necrosis factor- $\alpha$, which play a central role in renal damage. Moreover, cisplatin generates excessive reactive oxygen species (ROS) which stimulate mitogen activated protein kinase leading to renal injury and inflammation. As well as glucose-6-phosphate dehydrogenase and hexokinase activity are stimulated by cisplatin resulting in increasing free radical production and decrease of antioxidant production (Pan et al., 2014). Yao et al. (2007) mentioned that conversion of cisplatin to nephrotoxic molecules in the proximal tubule cells is required for cell injury. The highest concentration of cisplatin is found in cytosol, mitochondria, nuclei, and microsomes. Cisplatin is conjugated to glutathione and then metabolized to a reactive thiol, a potent nephrotoxin. Cisplatin can form monohydrated complexes by hydrolytic reactions; the monohydrated complex is more toxic to the renal cells than cisplatin.

In this work, single i.p injection of cisplatin $(6 \mathrm{mg} / \mathrm{kg})$ resulted in significant reduction of renal blood flow, this in agreement with (Bagnis et al., 2000). This result could be explained by Tusgaard et al. (2011) who demonstrated that cisplatin resulted in inhibition of cyclooxygenase enzyme with subsequent decrease in PGE2 in the kidney this may explain how cisplatin administration resulted in reduction of renal blood flow. Exenatide is believed to exert its beneficial effect in the endocrine pancreas by maintaining optimal $\beta$-cell mass and function by increasing the $\beta$-cell gene expression. In turn, this may lead to $\beta$-cell proliferation and neogenesis, thereby inhibiting apoptosis in pancreatic islet cells (Xu et al., 2009).

Administration of exenatide before induction of nephrotoxicity by cisplatin resulted in improvement of serum urea, serum creatinine and renal blood flow, this is in line with (Wang et al., 2019) who concluded that exenatide can mitigate the renal injury in diabetic rats.as well as Marcel et al. (2016) demonstrated that exenatide administration in healthy overweight men increases GFR, ERPF and glomerular pressure, probably by reducing afferent renal vascular resistance in an NO-dependent manner. To demonstrate the possible mechanisms of exenatide improving effect on kidney parameters, TNF- $\alpha$ level and reduced glutathione (GSH) level in renal tissue were measured. Treatment with exenatide $(10 \mathrm{mg} / \mathrm{kg} /$ day $)$ s.c for 4 weeks before induction of nephrotoxicity by cisplatin resulted in improvement of TNF- $\alpha$ level in renal tissue this result is in agreement with Chaudhuri et al. (2012) who reported that exenatide exerts a rapid antiinflammatory effect at the cellular and molecular level when administrated to obese patients. Moreover, administration of exenatide (induction of nephrotoxicity by cisplatin resulted in improvement of reduced glutathione (GSH) level in renal tissue pointing to antioxidant activity. Our results were in consistence with El-Gohary and Said (2015) who cited that exenatide has a protective role against ischemia reperfusion in diabetic rats. On the basis of the above mentioned data the present work can postulate that therapy with cisplatin, it is recommended to administrate exenatide before or concomitantly in order to protect against potential induction of nephrotoxicity by cisplatin through its anti-inflammatory and antioxidant activities. Moreover, this renoprotective effect of exenatide is not attributed to its antidiabetic action but it is a direct action regardless of presence of hyperglycemia.

\section{Conclusion}

From the results of the present study it can be concluded that the use of exenatide improved the biochemical and histopathological changes that occur in the renal tissue by cisplatin.

\section{Conflicts of interest}

The authors had no conflicts of interest to declare in relation to this article.

\section{References}

[1] Bagnis C, Beaufils H, Jacquiaud C, Adabra Y, Jouanneau C, Nahour G, Bourbouze R, Jacobs C, Deray G (2000): Erythropoietin enhances recovery after cisplatin induced acute renal failure in the rat. Nephrology Dialysis Transplantation. 16: 932-938. https://doi.org/10.1093/ndt/16.5.932.

[2] Bhoomika M, Patel N, Deepak D (2013): Combination of Telmisartan with Cisplatin Controls Oral Cancer Cachexia in Rats. BioMed Research International. Article ID 642848, 10 pages. https://doi.org/10.1155/2013/642848.

[3] Chaudhuri Ajay, Ghanim Husam, Vora Mehul, Sia Chang Ling, Korzeniewski Kelly, Dhindsa Sandeep, Makdissi Antoine, Dandona Paresh (2012): Exenatide Exerts a Potent Antiinflammatory Effect, The Journal of Clinical Endocrinology \& Metabolism.97: 198-207. https://doi.org/10.1210/jc.2011-1508.

[4] Decloedt E and Maartens G (2011): Drug-induced renal injury. The kidney plays an important role in the elimination of many drugs and their metabolites.CME.29: 252-256. 
[5] Dury RAB and Wallington EA (1967): Carleton Histological Technique. 4th ed. Oxford University Press, Oxford, P. 129.

[6] Efendic S, Karlander S, Vranic M (1988): Mild type II diabetes markedly increases glucose cycling in the postabsorptive state and during glucose infusion irrespective of obesity. J Clin Invest., 81: 1953- 1961. https://doi.org/10.1172/JCI113543.

[7] El-Gohary OA and Said MA (2015): Protective effect of exenatide (glucagon-like peptide-1 receptor agonist) on renal ischemia-reperfusion injury in diabetic rats. Benha Med J; 33:24-30. https://doi.org/10.4103/1110-208X.194384.

[8] Hasiyeti L, Yanzhang L, Wenpeng C, Xiaopeng T, Heather N, Xinyu Q, Shuxia W (2013): Increasing cGMP-dependent protein kinase I activity attenuates cisplatin-induced kidney injury through protection of mitochondria function.Am J Physiol Renal Physiol.305: 881-900. https://doi.org/10.1152/ajprenal.00192.2013.

[9] Haywood JR, Sahffer RA, Fastenow C (1981): Regional blood flow measurement with Pulsed doppler flowmeter in conscious rats. Am J Physical.241: 273-278. https://doi.org/10.1152/ajpheart.1981.241.2.H273.

[10] Holman RR, Bethel MA, Mentz RJ, Thompson VP, Lokhnygina Y, Buse JB, et al. (2017): Effects of Once-Weekly Exenatide on Cardiovascular Outcomes in Type 2 Diabetes. N. Engl. J. Med. 28; 377(13):1228-1239. https://doi.org/10.1056/NEJMoa1612917.

[11] Kaplan A (1984): Urea. Kaplan A et al. Clin Chem the C. V Mosby Co.St Louis Toronto Princeton. $1257-1260$ and 437 and 418.

[12] Koole C, Reynolds CA, Mobarec JC, Hick C, Sexton PM, Sakmar TP (April 2017): "Genetically encoded photocross-linkers determine the biological binding site of exendin-4 peptide in the N-terminal domain of the intact human glucagon-like peptide-1 receptor (GLP-1R)". The Journal of Biological Chemistry. 292 (17): 7131-7144. https://doi.org/10.1074/jbc.M117.779496.

[13] Marcel H. A. Muskiet, Lennart Tonneijck, Mark M. Smits, Mark H. H. Kramer Michaela Diamant, Jaap A. Joles, Daniël H. van Raalte (2016): Acute renal haemodynamic effects of glucagon-like peptide-1 receptor agonist exenatide in healthy overweight men. Diabetes Obes Metab; 18: 178-185. https://doi.org/10.1111/dom.12601.

[14] Mohamed A A, Ashraf M, Abdel-Moneim O, Elmenshawy M, Mohamed A E (2014): Hemin Attenuates Cisplatin-Induced Acute Renal Injury in Male Rats. Oxidative Medicine and Cellular Longevity. Article ID 476430, 9 pages. https://doi.org/10.1155/2014/476430.

[15] Murray RL (1984): creatinine. Kaplan A et al. Clin Chem The C. V Mosby Co.St Louis Toronto Princeton. , $1261-1266$ and 418.

[16] Noori S, Nasir K, Mahboob T (2009): Effect of cocoa powder on oxidant /antioxidant in liver, heart and kidney tissue of rats. The Journal of Animal \& Plant Sciences.4: 174-178.

[17] Ozkok A and Charles LE (2014): Pathophysiology of Cisplatin-Induced Acute Kidney Injury. BioMed Research International. Article ID 967826, 17 pages. https://doi.org/10.1155/2014/967826.

[18] Pan H, Shen K, Wang X, Meng H, Wang C, Jin B (2014): Protective Effect of Metalloporphyrins against Cisplatin-Induced Kidney Injury in Mice. J Am Soc Nephrol. 12: 2683-2690.

[19] Parasuraman S, Raveendran R, Kesavan R (2010): Blood sample collection in small laboratory animals. J Pharmacol . Pharmacother. 1: 87-93. https://doi.org/10.4103/0976-500X.72350.

[20] Saad SY and Al-Rikabi AC (2002): Protection Effects of Taurine Supplementation against Cisplatin-Induced Nephrotoxicity in Rats.Chemotherapy.48:42-48. https://doi.org/10.1159/000048587.

[21] Tanaka K, Masaki Y, Tanaka M, Miyazaki M, Enjoji M, Nakamuta M, et al. (2014): Exenatide improves hepatic steatosis by enhancing lipid use in adipose tissue in non-diabetic rats. World J Gastroenterol; 20(10): 2653-2663. https://doi.org/10.3748/wjg.v20.i10.2653.

[22] Tetsuhiro Tanaka1, Yoshiki Higashijima1, Takehiko Wada1 and Masaomi Nangaku (2014): The potential for renoprotection with incretin-base drugs Kidney International. 86: 701-711. https://doi.org/10.1038/ki.2014.236.

[23] Tusgaard B, Nørregaard R, Jensen A M, Wang G, Topcu S O, Wang Y, Nielsen S, Frøkiaer J (2011): Cisplatin decreases renal cyclooxygenase-2 expression and activity in rats. Acta physiologica (Oxford, England) .202: 79-90. https://doi.org/10.1111/j.1748-1716.2011.02257.x.

[24] Wang X, Li Z, Huang X, Li F, Liu J, Li Z, Bai D(2019): An experimental study of exenatide effects on renal injury in diabetic rats. Acta Cir. Bras., 34 (1): e20190010000001. https://doi.org/10.1590/s0102-865020190010000001.

[25] Xu Y, Wei Z, Zhang Z, Xing Q, Hu P, Zhang X, et al. (2009): No association of the insulin gene VNTR polymorphism with polycystic ovary syndrome in a Han Chinese population. Reproductive Biology and Endocrinology, 7: 1-5. https://doi.org/10.1186/1477-7827-7-141.

[26] Yao X, Panichpisal K, Kurtzman N, Nugent K (2007): Cisplatin Nephrotoxicity: A Review. Am J Med Sci. 334:115-124. https://doi.org/10.1097/MAJ.0b013e31812dfe1e. 